\section{International Scientific Journal Theoretical \& Applied Science}

p-ISSN: 2308-4944 (print) $\quad$ e-ISSN: 2409-0085 (online)

Year: 2015 Issue: 04 Volume: 24

Published: $30.04 .2015 \quad$ http://T-Science.org
Maharram Jalal Huseinov

Azerbaijan State Agrarian University Ganja, Azerbaijan

Vahid Tofig Amrahov

Azerbaijan State Agrarian University

Ganja, Azerbaijan

1-hasan@hotmail.com

SECTION 31. Economic research, finance, innovation, risk management.

\title{
ABOUT THE PRODUCTION DIVERSIFICATION ISSUES IN AGRICULTURE
}

Abstract: Special attention is paid to scientific justification of diversification by highlighting dynamic reaction to the changing economic factor in the background effect of natural factors of the agricultural productions in article. Main directions that make profitable results in agriculture, are determined by the latest researches and analysis.

Key words: market conditions, diversification, specialization, structural changes, economic efficiency, demand.

\section{Language: English}

Citation: Huseinov MJ, Amrahov VT (2015) ABOUT THE PRODUCTION DIVERSIFICATION ISSUES IN AGRICULTURE. ISJ Theoretical \& Applied Science 04 (24): 174-176.

Soi: http://s-o-i.org/1.1/TAS*04(24)31 Doi: crossef http://dx.doi.org/10.15863/TAS.2015.04.24.31

\section{Introduction}

The changes in the agriculture production structure as an important sphere in the economy cause to the formation of the most effective production spheres. In this regard, nowadays the main trends in the diversification of agricultural products can be considered the Market Conditions. More preciously, according to the changes taking place in the market conditions, the priority of the production directions must be determined in the agricultural production. So, formation of the diversification strategy in the agriculture actually requires justification of the process itself. In this regard, in the agricultural production depending on the market conditions and its demand, economic justification of the diversification process, increasing economic effectiveness of the production, determining the most favorable production areas and etc. are the important conditions of the preparation of the strategy. In its turn, this serves to the increasing of the effectiveness of the usage the production tools and labor resources by effective use the naturaleconomic conditions, increase the labor productivity.

The improvement of the payment opportunities of the demand at the expense of the local production is a main issue in the implementation of the diversification process which leading to the structural changes in agriculture.

In this regard, in order to adaptation of the agriculture production specialization to the market conditions, which is directly related to diversification, creation of market infrastructure for the development of the priority areas, and adaptation to the modern demands of the regional exchange system is particularly important.

Diversificaton shows itself as a main economic process implying development and determination of the most economical effective producton areas. In this case, the formation of the branches, thatare not relate to the main production is especially dominated.

Though, the above-mentioned directions of diversification are characteristic for all spheres of the economic, in terms of agriculture features the production diversification is characterized by a different substance. And this requires new approaches during researches, determining its main directions and types. Including the area criterion carried out in the agriculture, diversification requires 3 forms: production, finance and marketing. In fact, in globalization, having a deep meaning diversification shows itself as a main activity area, especially in the production, finance and marketing sphere of the enterprise. The production diversification characterizes the variety of production types, which provides purchasing various product or expansion of the sorts in the enterprises. Sphere diversification is different with a increasing of the spheres which are technologically related with each other in all stages of agricultural production in enterprises, as well as with a development of the 
distinguished from others with its utilized production tools, and final output. Similar situation for the production diversification is distinctive for the concrete product type.

The financial diversification is distinctive with a diversity of financial activities, in this context it is realized as a possibility of achievement by implementation of different short-term and long-term financial investments in the enterprise. Meaning of the diversification is met as the enterprises, serving several markets at the same time. But some economists' approaches to the diversification as a strategy reducing risks in production and exchange sphere and increasing financial sustainability.

\section{Materials and research methods}

Researches show that, the changes in the structure of the production areas, in most cases, occur spontaneously and such spontaneous making decisions are accompanied by certain risks. In particular, in accordance with changes in market conditions, the diversification priorities of the agriculture are being determined. So, the improvement of the payment opportunities of the demand at the expense of the local production is the main issues in the implementation of the structural changes in the market. In this regard, for the adaptation of the agricultural production to the market conditions and improvement of the more effective production areas are very important to form the most improved exchange systems. Researches show that, diversification is a main toolbar of the increasing the economic effectiveness and increasing labor productivity of the specialization of the agricultural production based on economic strategy of the enterprises as an objective legality. It should be noted that, as to all spheres of the economy, the process of social division of labor is one of the characteristic feature of the agriculture. Social division of labor comes forward from the specific features of the agricultural production, and from the economic and natural legality of expanded reproduction process. The economic and natural legality of the expanded reproduction process, in its turn, significantly influence to the level of the social division of labor, also to the level of the production specialization in the agriculture. While increasing the development level, the specialization of the labor and distribution are deepening enough. It is possible to implement scientific and technical progress in all spheres of the economy on the base of social division of labor. This process results with an increasing labor productivity, continuous improvement of the technologies, used in production process, increasing of the production experience and continuously expansion of the public production. So, the progress of the social division of labor causes with a continuous organization and improvement of production process.
It should be noted that, social division of labor is defined with a specialization of production. The specialization of production serves to the effective use of the natural-economic conditions of the different regions and also to the increasing effective use of natural resources and production tools. Researches show that the specialization of production has a quality features. The quality demands of the agriculture specialization are characterized with a production composition and with the relations between them. Quantitative point of view, the specialization of the production is characterized by the volume ratio of the proportion between interact spheres. So, the characteristic feature of the both sides is to have a certain size and proportion and to provide the ratio between proportions of the areas. Agriculture directly depends on the development level of the productive forces and the deepening process of the diversification, which results with a change of the specialization forms in the experience of the well-developed countries. Thus, it is impossible to define the productive forces and the development directions of the technical progress without taking into account the changes happening in the specialization of the agricultural production.

Efficient allocation of the agriculture on the natural-economic areas creates favorable conditions for increase of production and as well as, the decrease of production expenses. Such features of the allocation of the agricultural production as a result, leading to the reduction of the expenses, dealing with a product transportation by creating efficient usage conditions of the soil, material, finance and labor resources. Allocation of the agriculture on the territory of the country plays an important role on the efficient distribution of the all factors of the expanded reproduction. Naturally, all of these result with a payment of the demand at the expense of the local production in the agriculture area, serving to the economic progress in some areas. Thus, efficient allocation of the agricultural production serves to the re-qualification on the basis of the market conditions, increasing the level of the self-reliance in agricultural field, also increasing competitiveness of the products in the internal and external market. As is known, each economic region engaged in the agricultural production has a specific natural and economic conditions and this factor considerable impact on the production allocation. A number of large farms formed as a result of the allocation of the agricultural production in the favorable economic region in the well-developed countries. These farms have a special favorable influence in the agricultural area, as well as, in the internal and external markets.

Naturally, creating large farms play an important role in the application of the crop rotation system and in the increase of productivity, which caused by decreasing expenses in the production 
process. Allocation of the large farms in the suburban areas results with a facilitation of the production conditions. The one of the most important factors of the preference of production specialization is expansion of the applied scientific and advanced practice opportunities. This becomes the main factor of the introduction of progressive forms of work organization, the use of the new technologies and qualified staffs in the production and the success of expanded reproduction. It would be considerable to note that, if we take into account the providing economic independence of the entity is the most important feature of the market economic system; we can note as the most important conditions the advanced organization of the production and increasing economic efficiency in the diversification process. Therefore, the implementation of the measures directed at the expansion of the economic opportunities of the agricultural commodity producers and the production diversification, show its relevance sharply.

\section{Conclusion}

Scientific justification of the diversification of the agricultural production is a particular important issue and it leads to the fairly dynamic reaction to the changing economic factors in the background of the influence of the natural factors. In general, the fundamental changes are taking place in the production structure with an influence of the natural factors. So, it results with a formation of specialized regions in the main types of the agricultural production. Under certain natural conditions, deepening the diversification of the agricultural production plays significant role in the development of the high-income areas and households. Summarizing the above results, it can be noted the following directions, which will lead to the effective conclusion of the production diversification in the agricultural field:

1) Diversification strategy creates favorable conditions to the increase the possibility of a rapid response to the changes happening in market conditions and also collection and systematization the information on the market such as - information about supply and demand, competitive environment, price level, purchasing ability, consumers` tastes and etc. Diversification process creates conditions to form habit and ability for the new production, according to the market demand for the agricultural producers besides the traditional manufacturing sectors. This, in its turn requires a new approach to the development of intelligence to the organization of production and management issues.

2) Formation of diversification strategy allows to the enterprises in agricultural sector to determine economically more efficient areas before the start of the production process.

3) Diversification process that giving an opportunity to determine economically more advantageous production areas, acts as an guarantor of financial stability of the institutions beforehand by "insuring" risks dealing with the result of the production and sales. Diversification process becomes a stimulating factor involving innovation in the production, in terms of competitive production.

4) Diversification can be an impetus mechanism of the economic-developed agricultural enterprises as an important strategy, regulating the relationship between production and market, producers and consumers, supply and demand.

Results of the production diversification are classified as natural, economic and social factors. Though, the expansion the newest achievements of the technical progress in production and the increase level of the industrial areas in the agriculture, the natural factors are fairly dominated in agriculture.

\section{References:}

1. Doff R (2007) Risk Management for Insurers. Risk Control, Economic Capital and Solvency. Risk Books, London.

2. Gort M (1962) Diversification and integration in American industry. Princeton: Princeton University Press, 508 p.

3. Hürlimann W (2009) Optimization of the Nonlife Insurance Risk Diversification in Solvency. In.: Cruz., M. (ed.).

4. Lankina VE (2006) Management organization. Taganrog: TRTU, 304 p.
5. Pakchomova NV, Richter KK (2009) Industrial economics and public policy. Moscow: Economics, $533 \mathrm{p}$.

6. Voytovich UA (2010) Model diversification of the development strategy of the company. Economics and Management. № 8 (69).

7. Zhulina EQ, Myagkova TL, Katsuba OB (2008) Diversification of the company. Moscow: Economics, 310 p. 